\title{
Comparative studies of silicon from rice husk ash and natural quartz
}

\author{
${ }^{1}$ Onojah, A., ${ }^{1}$ Amah, A. N. and ${ }^{2}$ Ayomanor, B. 0. \\ ${ }^{1}$ Department of Physics, University of Agriculture Makurdi Nigeria \\ ${ }^{2}$ Federal Polytechnic, Nasarawa, Nasarawa State, Nigeria
}

\begin{abstract}
Metallothermic process was applied to both rice husk ash and natural quartz as standard ore for production of technical grade polysilicon. Thus the rice husk samples were subjected to thermal treatment at $1000^{\circ} \mathrm{C}$ to extract the silica. The silica from rice husk ash and powdered natural quartz were subsequently analysed for the initial impurities and treated with magnesium powder at $1100^{\circ} \mathrm{C}$. The magnesium reduction of these oxides resulted in higher purity silicon from the rice husk ash than the crystalline natural quartz; however the two sources of silica gave silicon purities in the range of $97-98 \%$. This range of purity meets the requirement for steel production and as starting raw material for the semiconductor grade silicon.
\end{abstract}

Keywords: Rice husk ash, x-ray flourescene, polysilicon

\section{INTRODUCTION}

Two main methods are currently used for the industrial production of technical grade silicon (metallurgical); the electric arc method and the metallothermic process with magnesium and calcium $(1,2)$. The most widely used method for silicon production is the submerged electric arc method. In this method a non stoichometric composition of carbon and silica (silica in excess) are heated to about $2000^{\circ} \mathrm{C}$ in arc, resulting in the reduction of silica to silicon The reaction for the silicon production is via three routes:

$$
\begin{aligned}
& \mathrm{SiO}_{2}+\mathrm{C}=\mathrm{Si}+\mathrm{CO}_{2} \\
& \mathrm{SiO}_{2}+2 \mathrm{C}=\mathrm{Si}+2 \mathrm{CO} \\
& \mathrm{SiO}_{2}+2 \mathrm{C}=\mathrm{SiC}+\mathrm{CO}_{2}
\end{aligned}
$$

The excess silica in the charge combines with the carbide in the furnace to produce the silicon

$2 \mathrm{SiC}+\mathrm{SiO}_{2}=3 \mathrm{Si}+2 \mathrm{CO}$

The second method, a much more easily adaptable to small scale, takes advantage of the high reactivity of magnesium or calcium and the solubility of their oxides in acids for easy dissolution.

$\mathrm{SiO}_{2}+2 \mathrm{Mg}=\mathrm{Si}+2 \mathrm{MgO}$

Rice husk ash (RHS) contain silica in the range of 83 $-97 \%$ depending on the variety of crop, geographical location and fertiliser application (3). This range of purity falls within the range of sand and quartz used for industrial production of metallurgical grade silicon.
Rice husk represents a vast industrial waste. Several studies have shown that raw materials like silicon carbide (4), silicon nitride (5), glasses and ceramics (6) could be produced at quality compared to the present practice of using natural silica and quartzite deposits.

This work compares the relative ease of magnesium reduction of crystalline $\mathrm{RHA}$ and natural quartz under the same condition

\section{MATERIALS AND METHODS}

Pyrolysis of Rice husk: The rice husk samples from different locations were washed with water to remove mud and soluble dirt. They were subsequently leached in concentrated $\mathrm{HCL}$ at $80^{\circ} \mathrm{C}$ for 2 hours and rinsed with distilled water. 100 grams of each sample were pyrolysed at $1000^{\circ} \mathrm{C}$ in a muffle furnace for 3 hours. At this temperature, complete crystallisation of the rice husk was expected. Though amorphous RHA has high surface area, gives better reactivity and high purity silicon (7), for these reasons, amorphous RHA have been adapted as starting materials by most workers (8) but here it is necessary to place RHA on the same footing with the natural crystalline quartz.

Silica analysis: The three samples: two RHA and one pulverised natural quartz were chemically analysed for major impurities using X-ray fluorescence. The crystalline phases determined by X-ray diffractometer

Magnesium reduction of the silica: $5.0 \mathrm{~g}$ of each sample were pulverised and mixed thoroughly with 4 
$\mathrm{g}$ of magnesium in a mortal. This was subsequently transferred to crucible and heated for $5 \mathrm{hrs}$ at $1000^{\circ} \mathrm{C}$. The silica reacts with the magnesium to form magnesium oxide. The reactant was heated in $\mathrm{HCL}$ for $1 \mathrm{hr}$ to dissolve the $\mathrm{MgO}$ and the unreacted $\mathrm{Mg}$. The samples were washed with distilled water and dried in the oven. The product Silicon was then analysed for the associated impurities using XRF

\section{RESULTS}

The elemental composition of the RHA and the natural quartz as measured by XRF is in range of 91 to $96 \%$ silica and contained trace amount of $\mathrm{K}, \mathrm{Ca}$, $\mathrm{Ti}, \mathrm{Mn}, \mathrm{Fe}, \mathrm{Ni}, \mathrm{Cu}, \mathrm{Zn}, \mathrm{As}, \mathrm{Zr}$, and $\mathrm{Sr}$, as shown table 1 . Table 1 also shows these impurities after the magnesium reduction. The initial crystalline phases of the RHA and quartz are shown in figure 1

Table 1 Elemental composition of RHA and natural quartz before and after magnesium reduction

\begin{tabular}{|c|c|c|c|c|c|c|}
\hline & \multicolumn{3}{|c|}{$\begin{array}{c}\text { XRF Analysis of silica from RHA and } \\
\text { natural quartz }\end{array}$} & \multicolumn{3}{|c|}{$\begin{array}{l}\text { XRF Analysis of silicon from RHA and natural } \\
\text { quartz by Mg reduction }\end{array}$} \\
\hline Elements & RHA1 (\%) & $\mathrm{RHA} 2(\%)$ & $\begin{array}{c}\text { Quartz } \\
(\%)\end{array}$ & $\begin{array}{l}\text { Si from RHA1 } \\
(\%)\end{array}$ & $\begin{array}{l}\text { Si from RHA2 } \\
(\%)\end{array}$ & $\begin{array}{l}\text { Si from Quartz } \\
(\%)\end{array}$ \\
\hline $\mathrm{Si}$ & 95.03 & 91.30 & 95.00 & 96.73 & 98.26 & 97.66 \\
\hline K & 1.26 & 0.68 & 0.80 & 0.12 & 0.12 & 0.26 \\
\hline $\mathrm{Ca}$ & 0.90 & 2.03 & 1.40 & 0.11 & 0.06 & 0.08 \\
\hline $\mathrm{Ti}$ & 0.60 & 0.50 & 0.03 & 0.04 & 0.03 & 0.03 \\
\hline V & 0.002 & ND & 0.001 & 0.002 & ND & 0.001 \\
\hline $\mathrm{Cr}$ & 0.32 & 0.38 & 0.34 & ND & ND & 0.006 \\
\hline $\mathrm{Mn}$ & 0.27 & 0.14 & 0.02 & 0.008 & 0.01 & 0.01 \\
\hline $\mathrm{Fe}$ & 0.62 & 2.41 & 1.54 & 0.21 & 0.11 & 0.21 \\
\hline $\mathrm{Ni}$ & 0.008 & 0.005 & 0.06 & 0.008 & 0.004 & 0.02 \\
\hline $\mathrm{Cu}$ & 0.202 & 0.09 & 0.05 & 0.03 & 0.02 & 0.01 \\
\hline $\mathrm{Zn}$ & 0.203 & 0.58 & ND & 0.002 & 0.006 & ND \\
\hline $\mathrm{Rb}$ & ND & 0.005 & ND & ND & 0.001 & ND \\
\hline $\mathrm{Zr}$ & 0.02 & 0.05 & ND & ND & 0.01 & ND \\
\hline As & ND & 0.01 & 0.05 & ND & ND & 0.004 \\
\hline $\begin{array}{l}\text { Total } \\
\text { impurities }\end{array}$ & 4.05 & 6.88 & 4.29 & 0.53 & 0.37 & 0.63 \\
\hline
\end{tabular}


Am. J. Sci. Ind. Res., 2012, 3(3): 146-149

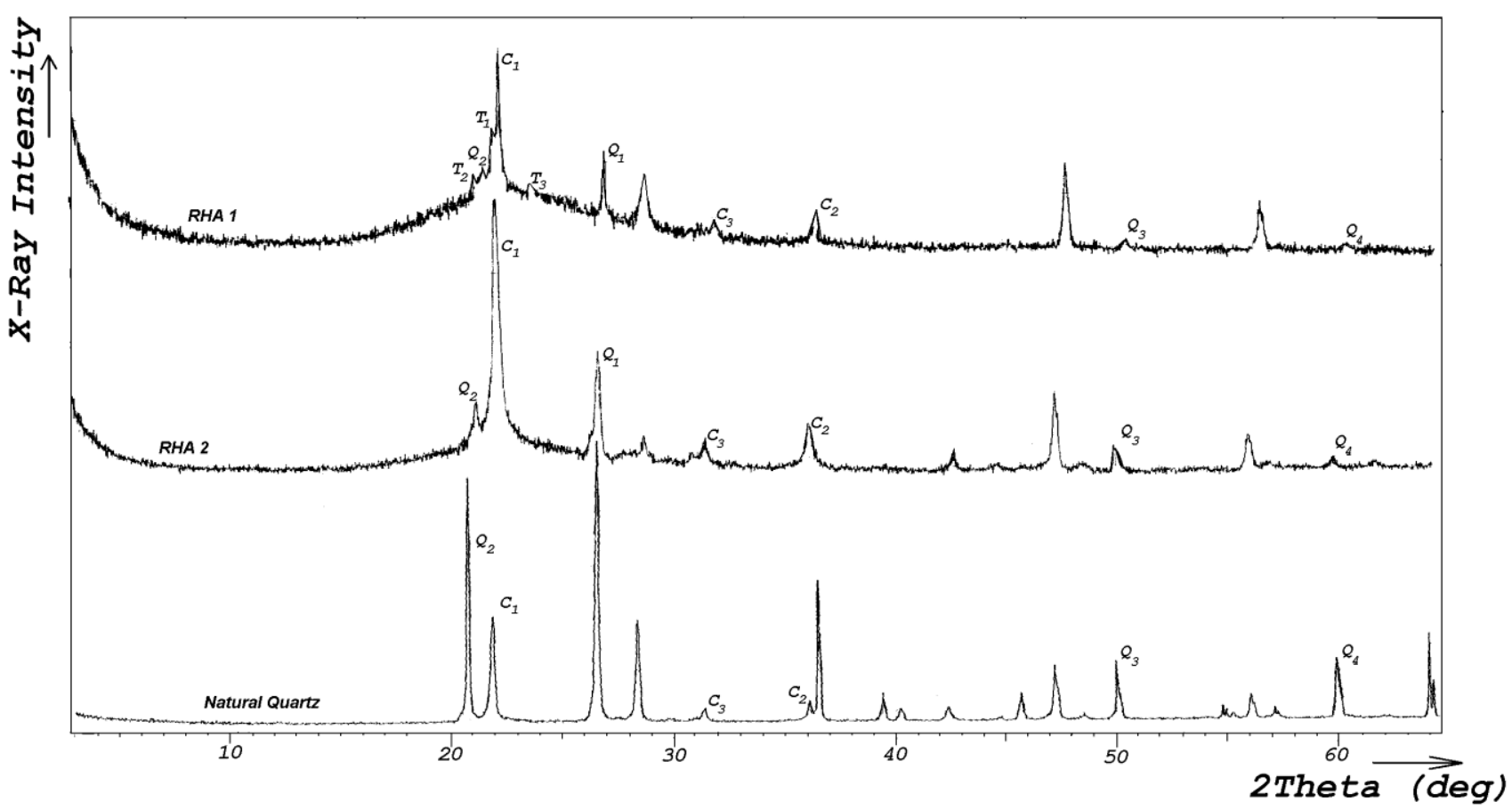

Fig. 1. X-Ray Diffractograms for RHA heated to $1000^{\circ} \mathrm{C}$ and Natural quartz (Symbols $Q, C$ and $T$ : Peak positions of Quartz, cristobalite and tridymite respectively)

\section{DISCUSSIONS}

The XRD patterns in figure 1 showed that the obtained silica from rice RHA were crystalline and of the same nature with that of natural quartz but the quartz peaks are much stronger thus more crystalline than the RHA. The purity level for silicon from RHA1 was $97 \%$, RHA2 $98 \%$ and natural quartz $98 \%$. Some impurities appeared difficult to remove. These impurities include ( $\mathrm{Fe}, \mathrm{Ca}$ and $\mathrm{K}$ \}. The final purity of silicon did not strictly depend on the initial purity of the starting material. Quartz which had relatively high impurity is more crystalline than the two RHA samples produced in three hours in a furnace, thus presents reduced surface area for $\mathrm{mg}$ reaction. The impurity reduction (RHA1- $4.5 \%$ to $0.53 \%$, RHA2 $6.88 \%$ to $0.37 \%$ and quartz $-4.29 \%$ to $0.63 \%$ ) are significant and therefore meet the needs for silicon steel production and starting raw material for the semiconductor grade in electronic industry

\section{CONCLUSIONS}

Silicon from the natural quartz, the standard industrial practice, gave the same range of purity with silicon from RHA. Thus relatively high purity RHA could be used as substitute for the raw material for metallurgical grade silicon in countries with low deposits of high grade silica sand and significant rice production industries

\section{REFERENCES}

Banerjee H.D , Sen S. and Acharya H. N. (1982) Investigations on the production of slilcon from rice Husks by the magnesium method. Materials Science and Engineering, Vol. 52 pp. 173-179

Mishra P. Chakraverty A. and Banerjee H. D (1985) Production and Purification of of silicon by calcium reduction of rice husk white ash. Journal of materials Science. Vol 20 pp 4387-4391.

Chandrasekar S., satyanarayana K. G. and Raghavan P.N. (2003) Processing, Properties and Applications of reactive Silica from Rice Husk- an Overview. Journal of Materials Science. Vol. 38, P 3159

Adylov G.T. , Faiziev S. A., Paizullakhanov M. S. Mukhsimov S. and Nodirmatov E. (2003) Silicon carbide materials obtained from rice husk. Technical Physics Letters, Vol. 29, no 3, pp. 221-223

Real C., Alcala M. D. and Criado J. M. (2004) Synthesis of silicon nitride from carbothermal reduction reduction of rice husks by the constant-rate-thermal analysis 
(CRTA) method. Journal of the American Ceramic Society, Vol. 87,no 1, pp. 75-78.

Haslinawati M. M, Matori K.A, Wahab Z.A. Sidek H. A. A and Zainal A. T.Effect of temperature on Ceramic from Rice Husk Ash. International Journal of Applied sciences IJBAS Vol:9 No 9. Pp. 111-117
Ekaphan S, Suspaluck S, and Pornthip A. (2004) Preparation of Silicon from rice hulls. Technical Digest of the international PVSEC - 14, Bangkok, Thailand, pp301-302

Amick J. A. (1982) Purification of rice hulls as a source of solar grade silicon for solar cells. Journal of Electrochemical Society vol. 129, pp. 864-866 